First Peoples Child \& Family Review

An Interdisciplinary Journal Honouring the Voices, Perspectives, and Knowledges of First Peoples through Research, Critical Analyses, Stories, Standpoints and Media Reviews

\title{
Truth Telling
}

Volume 9, numéro 2, 2014

Respect and Equity Through Reconciliation : special Edition by Children and Youth

URI : https://id.erudit.org/iderudit/1077947ar

DOI : https://doi.org/10.7202/1077947ar

Aller au sommaire du numéro

Éditeur(s)

First Nations Child and Family Caring Society of Canada

ISSN

1708-489X (imprimé)

2293-6610 (numérique)

Découvrir la revue

Citer ce document

(2014). Truth Telling. First Peoples Child \& Family Review, 9(2), 10-19.

https://doi.org/10.7202/1077947ar

All Rights Reserved (c) First Nations Child and Family Caring Society of Canada, 2014
Ce document est protégé par la loi sur le droit d'auteur. L'utilisation des services d'Érudit (y compris la reproduction) est assujettie à sa politique d'utilisation que vous pouvez consulter en ligne.

https://apropos.erudit.org/fr/usagers/politique-dutilisation/ 


\section{Truth Telling}

Talking about the inequities in child welfare, education and health for First Nations children and young people, and why First Nations cultures and languages are important to children and youth. 
Honorable Stephen Harper

Prime Minister of Canada

80 Wellington Street

Ottawa, ON

$\mathrm{K} 1 \mathrm{~A} 0 \mathrm{~A} 2$

\section{Dear Honorable Steven Harper}

I am writing to you today to express my absolute disgust and frustration with the way the Federal Government handles the care of First Nations children and their families. I find it completely shameful that without these people, Canada wouldn't be what it is today, yet we don't even have enough respect or love in our hearts to provide them with proper education, proper housing and clean drinking water

Every year, approximately 20,000 First Nations people have to make do and raise children on reserves that have no running water or sewage. As of July 2011, 126 First Nations communities with access to running water were under a Drinking Water Advisory that lasted well over a year 1 in 4 Indigenous persons live in dwellings that require major repairs, and when it comes to education, Indigenous children only receive $60 \%$ of what non-Indigenous counterparts receive.

I believe we must now ask ourselves; are these people any less important than the rest of the population? Did they do something to deserve such treatment? No, in fact, they gave us everything they have. Your office wouldn't even be standing today on the land it is on had it not been for the First Nations people. Just some food for thought. No human being should have to endure such conditions. We're all equals, and as Mahatma Ghandi says, we are all children of God. I thank you for taking the time to read this letter and I hope you will take these points into consideration and finally hear the pleas of the First Nations people that have been silenced for generations.

Yours truly,<smiles>C1CCCCCCCCCCCC1</smiles>

Sarah 
Hoda

École Featherston Drive

1801 Featherston Drive

Ottawa,ON

$\mathrm{K} 1 \mathrm{H} 6 \mathrm{P} 4$

Premier Ministre Stephen Harper

chambre des communes

Ottawa,ON

K1A OC6

Cher Monsieur Harper

Bonjour, je m'appelle Hoda. J'écris cette lettre parce que je veux que tous les enfants aient les mêmes droits et une bonne éducation. J'aime mon école parce qu'ils ont tout ce dont une école a besoin. Par exemple, un gymance, un laboratoire de ordinateurs,et on a 80 sources d'eau potable. L'école où shannen allait a seulement une source d'eau potable pour la communité. On a 400 élèves et 1 lavaboa pour chaque classe. Imagine que tes enfants va a un école avec seulement 1 lavabo et 1 toilet et il ya 350 élèves, qu'est ce que tu vas faire tu pouvais poursuivre le gouvernement si ton élève n'ont pas une bonne éducations.

Sincerement, Hoda 


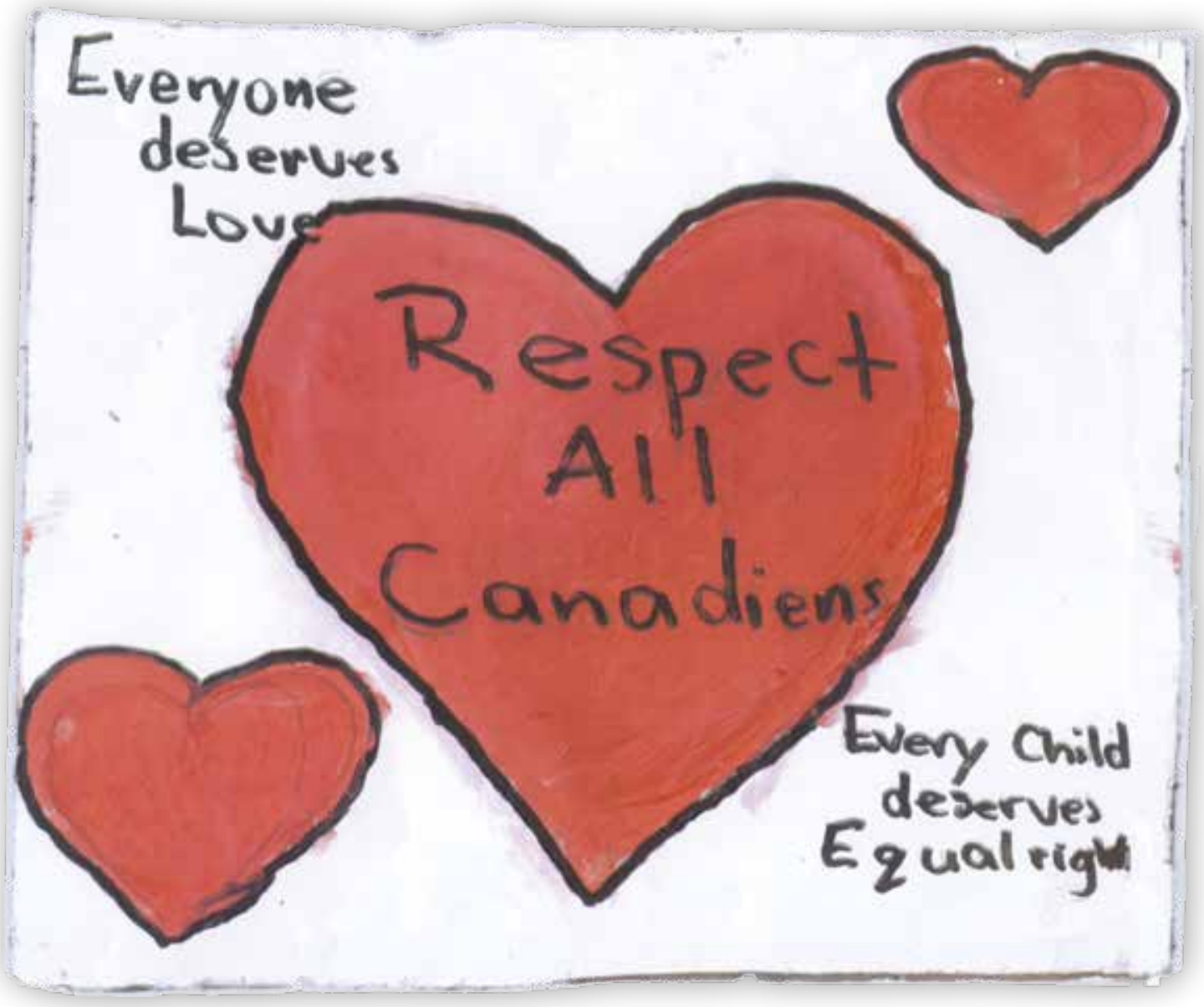

Hoda 


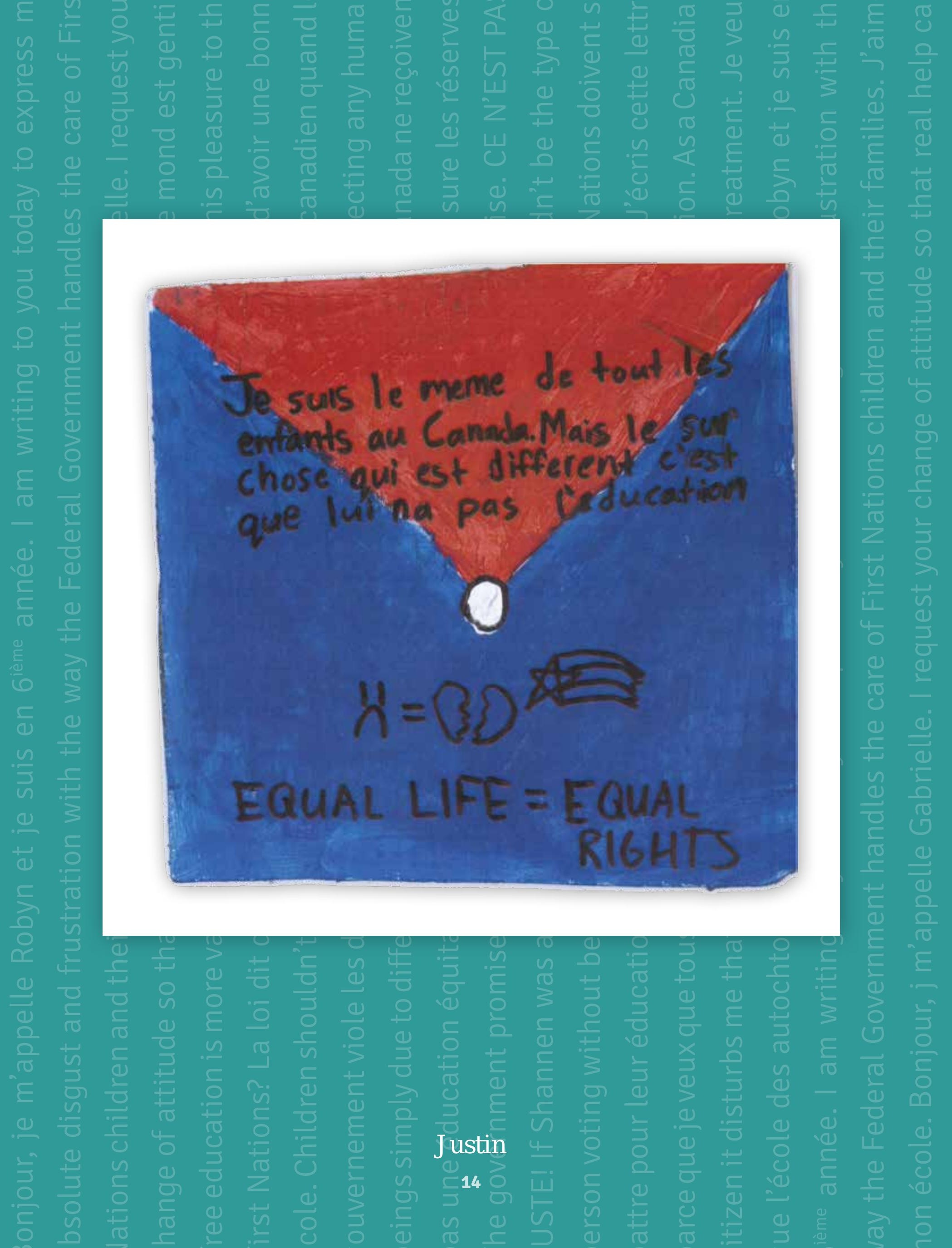


École Featherston Drive Public school

1801 Featherston Drive

Ottawa, ON KIH 6P4

Premier Ministre Stephen Harper

Chambers des Communes

Ottawa, ON KIA OAL

Cher Mr. Harper

Tous les jours quand je vais à l'école c'est normal parce que j'assume que tous les enfants ont les même droits et éducation. Quand j'avais 5-9 ans, je pensais que l'école était une place spéciale parce ce que tout le monde peut avoir l'éducation qu'ils ont besoin. Mais je ne sa vais pas que Les Premières Nations dans tout le Canada ne reçoivent pas une éducation équitable parce qu'ils/elles sont Premières Nations et vivent sur les réserves. On a besoin de ne se battre pour l'éducation. CE N'EST PAS JUSTE! On comprend la situation vous ne pouvez pas la cacher. On droit construire/réparer les écoles. J'ai une bonne école, pourquoi pas eux.

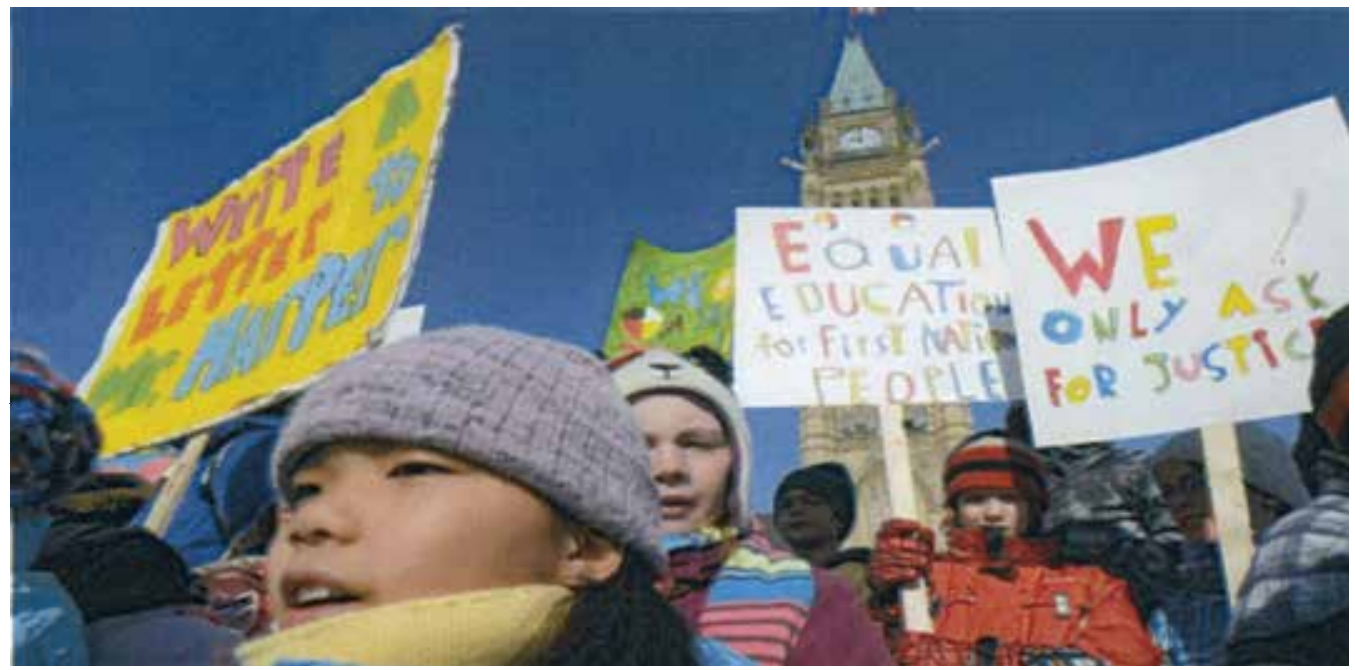




\section{It's Complicated}

\section{by Jillian}

It's complicated.

Some may say it's simple,

but it's much more.

It's complicated.

They're arrogant with their lucky lack of taxes and free education

and they ask for more.

You give them an inch and they take a mite,

but it's not that way.

And it never was that way.

Why do we pretend to see when our society turns a nascent blind eye?

Why do we listen to the name calling

spitting out of stereotyped mouths

engulfed in lies?

Most are oblivious

and oblivion is eating away at our deteriorated relationship

that never really had a stage before deteriorated.

We got off on the wrong foot

and never decided to switch feet.

Today we find ourselves with scarves of ignorance wrapped around our necks

so tight that nobody will speak the truth.

Scarves that leave scars of guitt,

And it will keep flowing into the house and destroying the foundation until we rebuild the house. You see, we need to reburitd the house

that towers over our dystopian relationship to make things better.

But it's not that simple

and some may say it's simple.

But it's not.

It's complicated. 


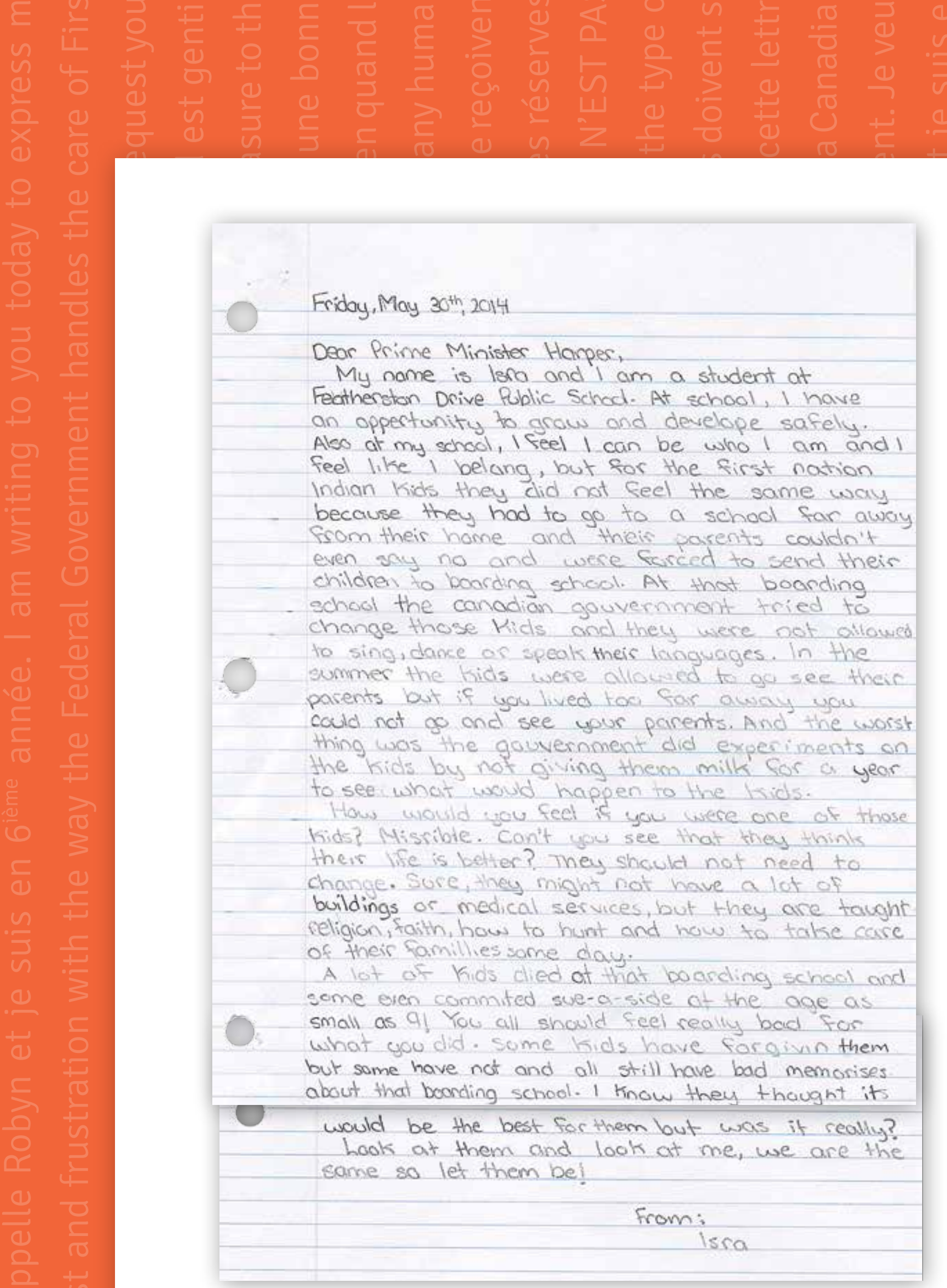

Friday, May 30m, 2014

Dear Prime Minister Harper

My name is lsra and I am a student at

Featherston Drive Public Schod. At school, I have

an oppertunity to grow and develope safely

Also at my school, I feel I can be who I am and I

feel like I belang, but for the first nation

because they had to go to a school far away

from their home and theis parent's couldn't even say no and were farced to send their children to boarding school. At that boanding school the canadian gouvernment tried to change those Kids and they wiere not atlowed to sing dame or upeak their tangueges. In the ummer the Kids were dlowed to go see their parents but if you lived tor far away you could not go and see your parents. And the worst the kids bu not giving them milk for a year to see what would happen to the krids.

How would you feel if you were one of those Kids? Misrible. Con't you see that they think their life is better? They should not need to change. Sore, they might not have a lot of buildings or medical services, but they are taught eligion, faith, how to hunt and how to take care of their famillies some day.

A lot of kids clied of that boarding school and pome eren commited sue-a-side of the age as What as af you all showl seel really bad for what you did. Some kids have for givin them about that boonding school. I know they thought it

hook at them and look at me, we are the same so let them be?

From:

isra 


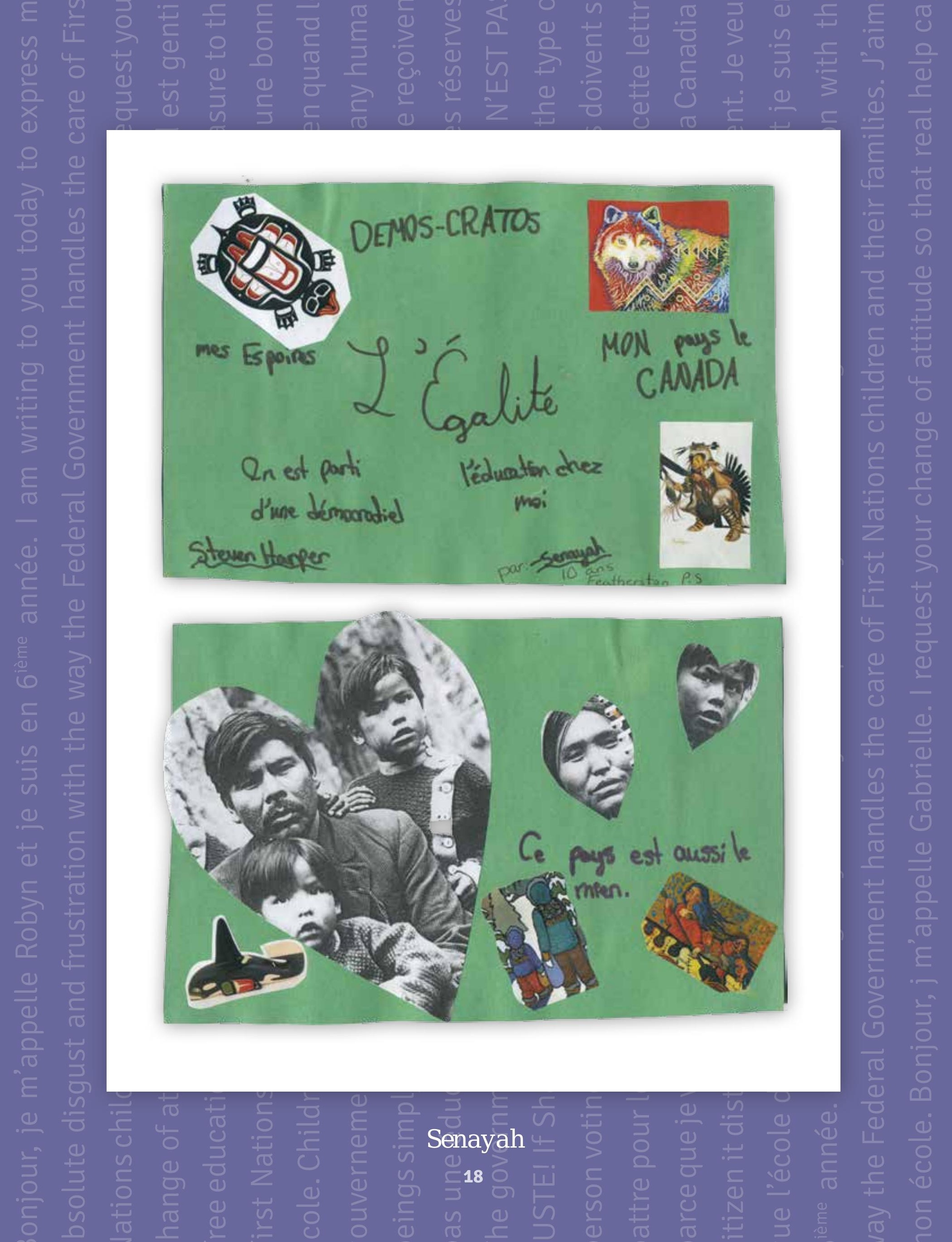




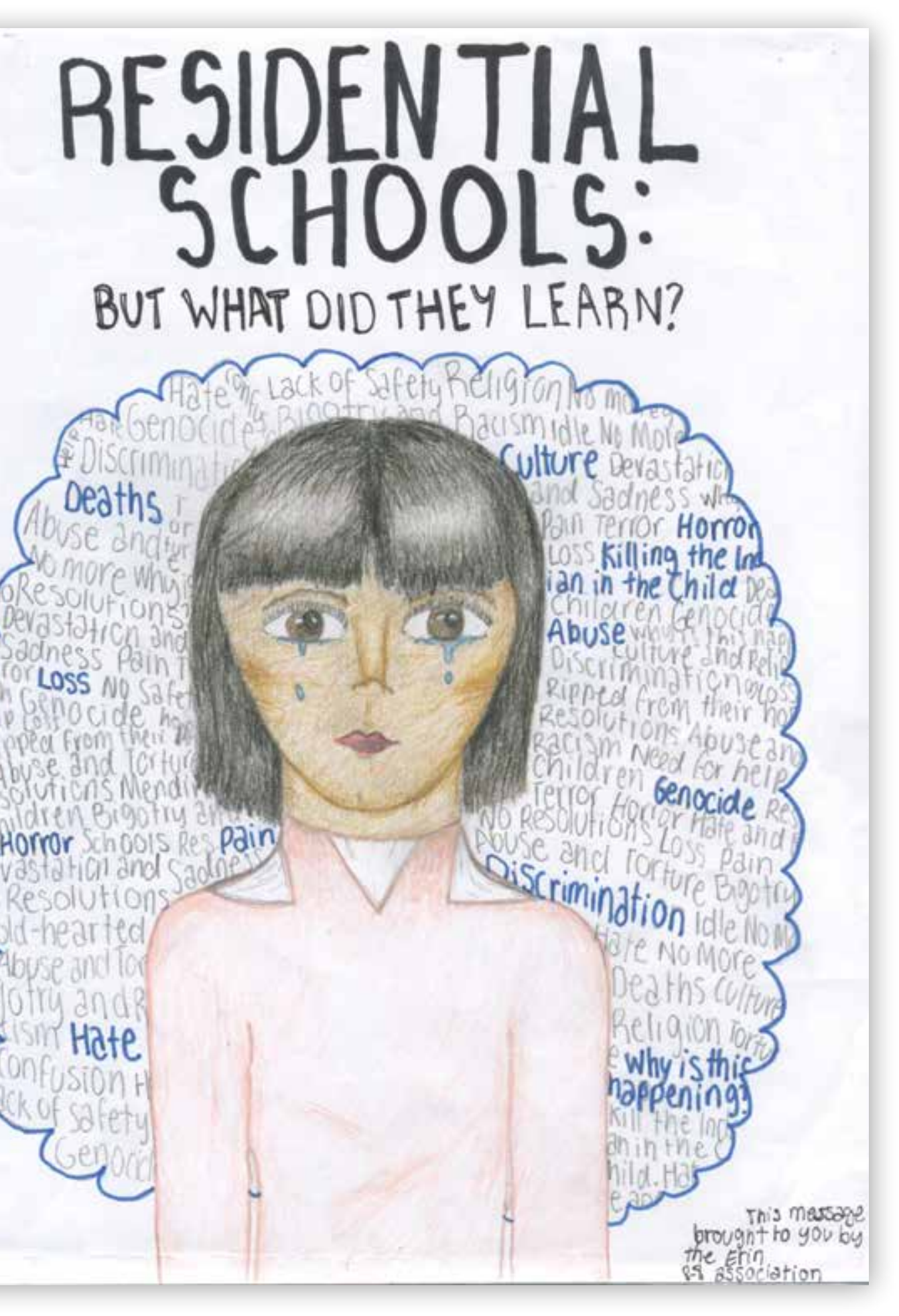

